\title{
MANUFACTURING THE "ONTOLOGICAL ENEMY" Socio-Political Construction of anti-Democracy Discourses among HTI Activists in Post-New Order Indonesia'
}

\author{
Masdar Hilmy \\ IAIN Sunan Ampel Surabaya, Indonesia
}

\begin{abstract}
The Indonesian Islamists' rejection of democracy, as this paper will demonstrate, is not monolithic; it is complex and multifaceted that is accompanied by a long process of argument building. This paper focuses its scope of analysis on Hizbut Tahrir Indonesia (HTI), a Middle Eastern-derived "transnational" Islamist movement that seeks to unite all Muslim nations all over the world under a Caliphate system. This paper argues that, in developing counter-discourses on democracy, the HTI activists employ both theological approach and modern socio-political narratives. It is also argued that the concept of enemy constructed by the HTI activists serves only as an ontological venture, and not existential one, for the purpose of self-fulfilling prophecy. The process of construction of the enemy follows the mode of binary opposition between the "authentic self" and the "corrupted other." This paper borrows much of its theoretical framework from Saphiro, Foucault, Berger and Luckmann, and still many others.
\end{abstract}

Key words: Democracy, Islamists, HTI, Khilajh Islarijeah.

\section{Introduction}

The fact that the majority of Indonesian Islamists reject the idea of democracy is nothing new. The bulk of research projects conducted

\footnotetext{
1 This paper is a part of my dissertation entitled "Islam, Islamism and Democracy: Islamist Discourses and Counter-Discourses on Democracy in Post-New Order Indonesia," submitted to the University of Melbourne, March 2007, and also my forthcoming book published by ISEAS Singapore.
} 
within the period of post-New Order Indonesia have underlined this. Most scholarly works have only arrived at the bold statement that Indonesian Islamists reject the notion of democracy. No further explanation has been made in terms of how and to what extent democracy is being rejected. As a consequence, the Islamists' rejection of democracy serves as a monolithic reference among researchers at home and abroad. Misconceptions and misunderstandings about the detailed picture of the Islamists' rejection of democracy are simply unavoidable along with the result of research projects on Islamism and democracy in Indonesia.

Those misconceptions and misunderstandings about the whole picture of Indonesian Islamism can lead to fatal theoretical oversimplification and reductionism about the subject that can further risk the image of entire Muslim community at large. One of the obvious cases in point is the sociological categorization often made by some "uninformed" researchers who often lump the word "Islamist" together with "fundamentalist" or even "terrorist" under a single bracket. This has to be made clear due in part to the fact that Islamism is not a discrete category disassociated from the socio-cultural web of Indonesian Islam in general. It is quite often that Islamism is a melting and at times sporadic category, the boundaries of which can both shrink and swell, contingent upon the circumstances surrounding the Muslim community in general. There is a vast ideological array in which radical phenomena are being integrated and shared by many different segments of Muslims in Indonesia. This is exactly the theoretical gap left by previous research projects that must be resolved in order to avoid such a fatal oversimplification and reductionism.

This paper is intended to fill the gap by focusing its analysis on socio-political construction of anti-democracy discourses among the HTI activists. The main question developed throughout the paper is how democracy is constructed as the enemy among the Islamists and on what basis it is rejected. The paper will be divided into three main parts as follows; the first part deals with theoretical framework used as its tool of analysis, the second presents a brief portrait of HTI, and the last part represents the main section of the paper, namely the sociopolitical construction of anti-democracy discourses among HTI activists. 


\section{Theoretical Framework}

As one of methodological breakthroughs in social sciences and humanities, the existence of constructivism deserves due appreciation. In the study of religions, Peter L. Berger is a pioneer for the birth of constructivism. ${ }^{2}$ The underlying assumption upon which this approach is erected is that all happens within any society is a result of construction process, and religion occupies a special locus within such a process. What is perceived as a reality by the society, thus, basically refers to the construction. No reality stands alone outside of the process of social construction. The entity of religion, therefore, is a part of social construction of its believers.

In Berger's theoretical framework, as a part of sociological process, the reality of religion undergoes a dialectical process through three main steps; externalization, objectivication, and internalization. Berger defines externalization as "the ongoing outpouring of human being into the world, both the physical and the mental activity of men."3 Externalization, in Berger's view, can be categorized as an anthropological need. A human being, as empirically observed, cannot be understood partially from the context of his/her involvement within the society where he/she lives. Humans cannot be perceived as $\mathrm{him} /$ herself, as being deprived from the societal structure. Since their early existence, humans are born and developed within socially defined roles and structures.

Berger defines objectivication as "the attainment by the products of this activity (again both physical and mental) of a reality that confronts its original producers as a facticity external to and other than themselves." 4 At this stage, as soon as humans are created, the world has become inseparable from them, something out there, occupying the distant spaces different from the creator, human. Within this distance lies the core concept of objectivication. Anything that the human has created has become an independent and separate object that is not easily touched, malleable and conquered by its creator. Even though all cultures are derived from the deep consciousness of human being, as soon as they are created they cannot be easily permeated and absorbed arbitrarily. Cultures are independent within their own space,

\footnotetext{
2 Peter L. Berger, The Sacred Canopy (New York \& London: Anchor Books, 1990).

${ }^{3}$ Ibid., p. 4.

${ }^{4}$ Ibid., p. 4.
} 
becoming objective reality that is independent from their creator, i.e. human.

Internalization, Berger argues, refers to "the absorption into consciousness of the objectivated world in such a way that the structures of this world come to determine the subjective structures of consciousness itself." 5 Internalization is a process of perceiving empirical reality created by human and permeating it into the deep structure of individual's cognition. As a process of construction, internalization constitutes subjective biases as a result of distortions of meaning in it. Soon after it serves as an objective reality, in the next step society plays as a formative agent for individual's consciousness. Along with the process of internalization, the objective reality he/she sees and perceives will become subjective reality deeply internalized within his/her consciousness.

Berger further argues that like cultures and languages, religion is the product of human's construction by which a sacred cosmology is formed. In other words, religion serves as cosmization in a sacred mode. ${ }^{6}$ By "sacred" here means a mysterious power beyond human's power but still associated with what is believed to occupy within a particular existence. This quality may be attributed to artificial matters, animals, humans, or objectivied human's cultures. There are sacred rocks, sacred tools, and sacred cows alike. There are also sacred leaders, as well as particular traditions or institutions. Space and time may be attributed with the same quality of sacredness, like sacred places or sacred seasons.

Historical manifestation about the sacredness takes different forms between one particular society and the other, although there is an agreement in several cultures (no matter whether the idea of sacredness is a result of cultural diffusion or deepest logics of religious imagination). The idea of sacredness is perceived as something sticking out from normal daily activities. Even though the idea of sacredness can be understood as something beyond people, in reality it refers to humans, associated with them. Sacred cosmology embodies within religion, therefore, overpower and embody humans. The sacred cosmology is faced by humans as a great reality outside of themselves.

\footnotetext{
5 Ibid., p. 15.

${ }^{6}$ Ibid., p. 25.
} 
Nevertheless, this reality refers to humans and puts them in a meaningful order of life.

In a similar vein, Olivier Roy argues that religion is a matter of construction rather than reality. He further asserts that "The many different Islam's (liberal, fundamentalist, conservative) with which we are familiar are more a construction than a reality." "7 This assumption is particularly justified by "erratic pattern" of life path of an individual, which represents more than a long lively journey of "becoming" than a stagnant enterprise. One may, at any point in time, live in a very liberal manner, then experience a spiritual crisis, and may later join an Islamic radical group before turning more "bourgeois" and perhaps becoming a community leader in his surroundings. For that reason, Roy insists that the culturalist approach fails to reveal the very reality of religion because it is mostly trapped in the shift of emphasis from discussing religion to religiosity. ${ }^{8}$ The issue of religion, within its time and space limits, is time and again exploited as a means for justifying one's quest for something in line with his interests.

It has commonly been argued that the processes of reconstruction and deconstruction are an integral part of the making of religion within which religious public debates over particular religious indictments are simply unavoidable. ${ }^{9}$ As a result, religious opinions are subject to the

\footnotetext{
7 This framework of thinking has long become an independent school of thought in the fields of Sociology and Philosophy called "constructivism." This theoretical construct is primarily based on the Kantian paradigm on the reality of human knowledge. In Kant's view, our knowledge is not in itself the authentic reflection of reality, because it is constructed on the basis of human categories. Human knowledge and experiences are therefore human constructions rather than a reflection of genuine reality. For further discussion on this issue, see, for instance, George Karuvelil, "Constructing 'God': A Contemporary Interpretation of Religion," HeyJ XLI (2000), pp. 25-46; cf. Michael Arbib and Mary Hesse, The Construction of Reality (Cambridge: Cambridge University Press, 1986).

8 Olivier Roy, Globalised Islam: The Search for a New Ummah (London: Hurst, 2004), p. 9.

9 Deconstruction is a method widely used in Philosophy to challenge, contest, or simply "interrogate" existing philosophical theories and concepts. This method has recently also been used in the context of religious studies, especially in Islamic studies by Muslim intellectuals such as Mohammed Arkoun. Derrida is one of the most acknowledged "prophets" of this method. He defines deconstruction as a method of "interrogating a concept, a word, a text, or a position. Just as a deconstruction of a philosophical problem neither solves it nor dissolves it, similarly, a deconstruction of a text or position is not a refutation of the text or position." For more detailed
} 
process of construction and deconstruction, mainly due to the fact that their meanings are publicly contested. In the course of the history of religious thought in Islam, nuances of change and continuity are omnipresent. ${ }^{10}$ This means that while some parts of religion are subject to change, some other parts of it are believed to remain unchanged. The process of confirmation, challenge, and validation of religious indictments will continue to occur as long as an institutional mechanism to do so exists in religion. In Islam, for instance, there exists such an institutional mechanism whose role is to validate or reinvigorate the old with the new, namely ijtibat through which a process of construction and deconstruction of religious indictments is the corollary. ${ }^{11}$

Warriors need enemies, without which the self will mean nothing. The entity of the enemy is not something constructed in a vacuum, socially and politically. This means that "if an enemy is not ontologically present in the nature of things, one must be manufactured."12 To Islamists, the word enemy can take different forms from time to time, contingent upon the context of when and where Islam is present. Berger and Luckmann itemize the steps through which a process of social construction proceeds: naming, legitimation, mythmaking, sedimentation, and ritual. ${ }^{13}$ The conception of an enemy begins with naming or "labeling," a crucial step in the

information on this issue see, for instance, Ralph Shain, "Situating Derrida: Between Kierkegaard and Hegel," Philosophy Today 44, No. 4 (Winter 2004), pp. 388-403.

${ }^{10}$ For a more detailed theoretical account on change and continuity in Islam see, for example, John Obert Voll, Islam, Continuity and Change in the Modern World (Boulder, Colorado: Westview Press, 1982).

11 Ijtibala derived from the Arabic root $\mathrm{j}-\mathrm{h}-\mathrm{d}$, meaning serious struggle, is a term commonly used in the context of Islamic jurisprudence (figh) to mean an intellectual struggle done by selected religious scholars to solve Muslims' contemporary problems which are not explicitly decreed in both pristine texts of Islam: the Qur'an and Hadith. For more detailed information on this see for example, B. Weiss, "Interpretation in Islamic Law: the Theory of Ijtihan' in I. Edge (ed.), The International Library of Essays in Law \& Legal Theory: Legal Cultures, 7 (Aldershot: Dartmouth, 1996), pp. 273-286. Cf. Wael B. Hallaq, "Was the gate of Ijtiha closed?," in I. Edge (ed.), The International Library of Essays in Law \& Legal Theory, pp. 287-325.

12 James A. Aho, This Thing of Darkness: A Sociology of the Enemy (Seattle and London: University of Washington Press, 1994), p. 26.

13 Peter Berger and Thomas Luckmann, The Social Construction of Reality (Garden City, N.Y.: Doubleday-Anchor, 1967). 
process of social construction. It is common in public discourses that defamatory labels are imposed onto persons, entities, acts, or situations that might not represent the reality precisely. This step is followed by legitimation, whereby the labels are validated. One of the vehicles for implementing this is the public degradation ceremony. The next step is mythmaking, in which a word and myth are built to support the construction of an enemy. To do this, authoritative jargon must be used, documenting how the victim's case fits the official "scientific" theory of evil. ${ }^{14}$ The next step is sedimentation, a step where a process of transmission of knowledge takes place from person to person, agent to agent. The culminating step in the social construction of an enemy is the ritual, where a process of self-fulfilling prophecy occurs. Despite their costs, they do provide a perverse sense of sacrifice. Routine combat against perceived internal and external enemies endlessly generates the very evildoers.

\section{The Portrait of Hizbut Tahrir Indonesia (HTI)}

Hizbut Tahrir etymologically means "Liberation Party". Originally, this movement was a transnational political party, established in 1952 in Jerusalem by Taqi $\gg$ l-Dipal-Nabhatr $>$ He himself was born in Palestine who had studied at the Al-Azhar University and the Dapal'Uluær in Cairo, Egypt. This learned man was a judge and a lecturer in Palestine, Jordan and Jerusalem. In 1948 he migrated to Beirut, Lebanon. From that time onwards he did not have a permanent place to live, because he migrated more often from one place to another between Jordan, Syria and Lebanon. After he passed away, his position had been replaced by 'Abd al-Qadir Zallum from Palestine.

As mentioned in its website, Hizbut Tahrir's objective is "to resume the Islamic way of life by establishing an Islamic State that executes the systems of Islam and carries its call to the world." 16 In relation to its construct of state, Hizbut Tahrir (HT) favors the theme of establishment of a transnational Islamic caliphate (al-Khilaferb alIslariyyah). ${ }^{17}$ In order to achieve its goals and ideals, HT claims to

\footnotetext{
${ }^{14}$ James A. Aho, This Thing of Darkness, p. 30.

${ }^{15}$ See, http://www.hizbuttahrir.org.uk.

16 Ibid.

${ }^{17}$ For more detailed information on the doctrine of Khilafah Islamiyah see, among others, Suha Taji-Farouki, A Fundamental Quest: Hizb al-Tabrir and the Search for the
} 
follow three steps of struggle (marbdlab): (1) Marbdlab Tathqif character building and cadre recruitment) which puts its emphasis on the establishment of the party's cadres, the framework for building the movement, and developing its followers with its organized and intensive character building materials; (2) Marbdlah Tafa ma'a alUmmah (interaction with communities) through which the organization hopes to make all elements of society aware that Islam is the only solution for their daily problems, and; (3) Marhdlab Istilam al-Hn/km (seizing power) through peaceful means. This is the culmination of the process where the final goals of HT, namely the implementation of the Islamic Shari or the Islamic state can be accomplished under its alKbila al-Islantiyab. ${ }^{18}$

Based on the three abovementioned steps, HTI sets up the following three missions: (1) To resume the life of Islam. The mission of HTI is to ensure the continuity of Islam and its implementation at a practical level; (2) To establish Khila Islarizh by extending networks among all elements of the Muslim world, and; (3) To provide education to the wider society in order to make them think and behave in an Islamic manner. ${ }^{19}$

In Indonesia, HTI was established in 1982 and was introduced by Abdurrahman al-Baghdadi, the leader of Hizbut Tahrir in Australia who moved to Bogor, West Java, at the invitation of $\mathrm{KH}$ Abdullah bin Nuh, the principal of pesantren Al-Ghazali and a lecturer at the Literature Faculty of the University of Indonesia (UI). ${ }^{20}$ During his stay in this city, he interacted with many Muslim activists from the mosque Al-Ghifari, which was the headquarter of Muslim activists in the Institute of Agriculture Bogor (IPB). ${ }^{21}$ Like the Tarbiyah movement,

Islamic Caliphate (London: Grey Seal, 1996). See also, Hizbut Tahrir, The Methodology of Hiz̧but-Tabrir for Change (London: Al-Khilafah Publications, n.d.).

18 "Hizbut Tahrir Indonesia: Dakwah Masjid yang Menggurita," Sabili, No. 9/XI, special edition, 2003, p. 143. Cf. Taqiyuddin Al-Nabhani, Pembentukan Partai Politik Islam (Bogor: Thariqul Izzah, 2002), p. 34.

${ }^{19}$ Endang Turmudi \& Riza Sihbudi (Eds.), Islam dan Radikalisme di Indonesia (Jakarta: LIPI Press, 2005), p. 277.

20 See Agus Salim, "The Rise of Hizbut Tahrir Indonesia (1982-2004): Its Political Opportunity Structure, Resource Mobilization, and Collective Action Frames" (Jakarta: UIN Syarif Hidayatullah Jakarta, Masters Thesis, 2005), p. 5.

21 “Hizbut Tahrir Indonesia: Dakwah Masjid yang Menggurita," pp. 142-3. 
HTI spread out rapidly around student circles through the network of "dakwah kampus", which reached its peak under the New Order when the Soeharto regime imposed a ban on all student political activities through the Campus Normalization Act in 1978. Since that time, like many other Islamic activist groups, HTI became a clandestine movement until the fall of New Order regime.

The ideas and ideology of HTI were disseminated through learning circles known as hllaqah. Through these hollaqabs the participants read HTI's publications which constitute such issues as Shabshizanh Islamijath (Islamic Personality), Fikr al-Islam (Islamic Thought), and NizgalIsla (Islamic System). Starting from this point, HTI started to propagate its ideology outside Bogor through campus networks known as Lembaga Dakwah Kampus (LDK/Campus Dakwah Institute) in several university campuses such as UNPAD Bandung, UI Jakarta, UGM Yogyakarta, IKIP Malang, UNAIR Surabaya, IKIP Surabaya, UNHAS Makassar - all of which are notably secular campuses - and eventually reached every province of the country.22

In 1987, KH Abdullah bin Nuh passed away and his position was taken over by local activists such as Muhammad Al-Khaththath and Muhammad Isma'il Yusanto as the spokesmen of the movement. HTI has gradually increased its membership and claimed to have more than 10.000 followers. In relation to this, Sadanand Dhume, a former Indonesia correspondent of the Far Eastern Economic Review and The Asian Wall Street Journal in Jakarta, observes that Hizbut Tahrir Indonesia has grown more rapidly than other Islamic radical groups, particularly in South Sulawesi, where Neo-Salafi movements are also active. ${ }^{23}$

Unlike other Islamist groups and organizations which are usually sporadic and less well-organized, HTI is one of the better-organized Islamist organizations in Indonesia, comprising mainly middle-class Muslims from relatively well-educated backgrounds. HTI and its activists, thus, is a typically modern organization. HTI serves as a reservoir for middle-class Muslims with a strong longing for spiritual

22 Elizabeth Fuller Collins, "Islam is the Solution: Dakwah and Democracy in Indonesia," unpublished paper, p. 9.

${ }^{23}$ Sadanand Dhume, "Hizbut Tahrir Using War in Iraq to Seek Converts," Far Eastern Economic Review (April 3, 2003), as cited by Elizabeth Fuller Collins, "Islam is the Solution: Dakwah and Democracy in Indonesia," p. 14. 
assistance. Within this organization lies a unique mixture between the elements of modernity and the elements of salafism, even though at times it is unclear whether it represents a version of indigenous or Arabicized Islam. ${ }^{24}$ This eclectic attitude in turn influences the stance it takes amidst the diverse Islamic movements in the country. As a result, it is not surprising that HTI tends to choose a moderate stance with an intellectual mode as its means of dakwah. Most of its members are attracted to the ideas of HTI not because of coercive indoctrination, but because of the intelligibility of the narratives on Islam provided by its ideologues. HTI mostly deploys international issues inflicting upon Islam and the Muslim world as the basis of its campaign towards the establishment of Khila Islarizath, even though its activists are also very much concerned with domestic social and political issues.

As mentioned earlier, HTI considers itself to be a political party, even though it is not registered as a party with the Departemen Kehakiman dan HAM (Ministry of Justice and Human Rights) to compete in general elections. HTI defines a political party in a broader sense as an organization that seeks to restore the existing political system and build it in the way it believes to be true. As a political party, HTI has three main characteristics: (1) This party bases itself on Islam as its ideology and rejects any man-made ideologies such as democracy and Pancasila; (2) It is a transnational organization in its scope due to the fact that HTI is a part of an international organization whose branches are spread all over the world, and; (3) Its activities are extraparliamentarian. That is why HTI does not want to be part of existing political parties which compete openly with one another in general elections. Nevertheless, HTI does not have social and educational bodies such as NU and Muhammadiyah. ${ }^{25} \mathrm{HTI}$, according to Ismail Yusanto, offers a comprehensive solution to the problems faced by human beings. In doing so, HTI starts with establishing a Muslim community by developing two main programs reflecting the elements of the community. The first program is called shakbshizath Islarrizath

${ }^{24}$ What struck me a lot is the fact that Ismail Yusanto, the spokesman of HTI, is fashionably modern and intellectually articulate. When I asked him for an interview, he proposed a high class hotel restaurant in Kuningan, a bustling business district in South Jakarta. This amazed me a lot because in this restaurant all kinds of people can be found, from domestic high-class businessmen to expatriate foreigners whose food taste is very much different to that of a Muslim activist such as Yusanto.

${ }^{25}$ Endang Turmudi and Riza Sihbudi (eds), Islam dan Radikalisme di Indonesia, p. 273. 
(Islamic personality), buttressed by two pillars of society empowerment; namely politics and economy. These pillars give impetus to the rise of Islamic economics (including Islamic noninterest banking system), Islamic politics, Dawlah Islamizarh, and eventually culminates in the Khila Islarrizah. In general, HTI is concerned with the attempt to develop an Islamic civilization (thaqa) Islarijab) comprising Islamic thought and Islamic law. In HTI's terms, there are three interrelated fundamental $A$ 's as a point of departure: $\operatorname{ara}$ viewpoint), afkary thought), and absalat (laws). ${ }^{26}$

As far as HTI's viewpoints are concerned, it is clear that this organization shares the same ideas with other Islamist organizations, such as al-Ikhwa al-Muslimu (IM) in Egypt, even though Yusanto rejects this assumption. ${ }^{27}$ In his opinion, IM differs from HTI in the approaches and strategies it adopts. IM puts prominent emphasis on the significance of individual nurture as a precondition of the Muslim community as reflected in Hasan Al-Hudaybi's statement, a leading figure of IM, that "establish dawlab Islamizath within yourself so that it can be erected on your earth." 28 On the other hand, HTI believes that the establishment of Muslim individuals and communities must be accompanied by the establishment of Dawlah Islamizath or Khilafth Islamizath. This is so because society does not only consist of individuals but also of interactions among these individuals. The crowd of individuals cannot give rise to an integrated society, but to a collection of individuals (jama hat is why a systemic approach, i.e. Khilafor Islamizarh, is needed to establish a systemic community.

Like NII, HTI was a clandestine movement during the New Order regime. ${ }^{29}$ The process of teaching and learning within the underground circle was carried out in a closed method so that it did not draw any suspicion from the government. It was not until Soeharto was dethroned that HTI declared its existence openly to the public. The collapse of the New Order regime has led to a paradigm shift in its

\footnotetext{
${ }^{26}$ Interview with Ismail Yusanto, Jakarta, 11 May 2005.

27 Ibid.

${ }^{28}$ Jamhari and Jajang Jahhroni, Gerakan Salafi Radikal di Indonesia (Jakarta: Rajawali Press, 2004), p. 175.

${ }^{29}$ Ibid., pp. 172-3. See also, Agus Salim, "The Rise of Hizbut Tahrir Indonesia," pp. 37-9.
} 
modus operandi from underground to a public movement. In this sense, HTI denies the accusation that indoctrination is the way it employs to disseminate its ideas to its members and wider public. What is apparent, instead, is the fact that dakwah is undertaken through a persuasive, open and critical method. Any segment of society is regarded as a potential cadre of HTI.

In the perspective of social movement theory, the stage of birth and development of HTI in Indonesia can be explained as follows. The first stage, marhdlah al-tathqif parallels with the so-called "Hibernation Phase" (1980-1999), where the movement operated secretively and clandestinely as a response to harsh measures by the government. This is a phase of guardianship and training of cadres. This phase was attributed to the strategy of the Prophet Muhammad in proselytizing the Meccan community to Islam during his early phase to avoid the resistance of the public. The second stage, tafa ma'a al-nas, can also be called as the "Formative Phase" (2000-2001), where HT engaged and interacted with the public. This formative phase began with the mobilization of around 5000 supporters to attend an international conference on the Khila Isla 2000. The third stage, Marbltah Istila al-Hatkm or the "Escalation Phase" (2002-2004), signifies the intense protest actions and demonstrations, and a variety of collective actions such as the issuance of official statements, marches, conferences, and visits to government and press offices. ${ }^{30}$

In 2007, HTI held a relatively successful first international conference on Khila at Gelora Bung Karno, the tenth largest stadium in the world and it equals with the Melbourne cricket ground. ${ }^{31}$ The conference was held on 12 August 2007, corresponding to 12 Rajab 1248, which is the Hijri date of the destruction of Khilafeth system in Turkey on 12 Rajab 1342. Over one hundred thousand attendants were expected to come to the conference. The conference was attended by HT leaders all around the world such as Shaikh Issam Ameera (HT Palestine), Shaikh Uthman Abu Khalil (HT Sudan),

\footnotetext{
30 Ibid., pp. 39-57.

31 See, http://www.khilafah.com/kcom/activism/asia/international-khilafah-conference-2007.html, accessed: 9 January 2008. See also, http://www.hizb.org.uk/hizb/global-photos/in-pictures-hti-international-khilafah-conference.html, accessed: 9 January 2008.
} 
Hasan Ko Nakata (Japan), and others. Two of the HT leaders scheduled to give speech in the conference, Imran Waheed (HT Britain) and Shaikh Ismail Al-Wahwah (HT Australia) were deported by the government as soon as they arrived at the Soekarno-Hatta airport. ${ }^{32}$ Some other local prominent figures also attended the conference such as Din Syamsuddin, the Chairman of Muhammadiyah, Abdullah Gymnastiar, a famous cleric and the principal of pesantren Darut Tauhid Bandung, and Amrullah Ahmad, the Secretary General of Majlis Ulama Indonesia (MUI/Indonesia Religious Scholars Council). ${ }^{33}$

It should be emphasized that in disseminating its ideas and ideology, HTI relies heavily on its own publications. It has so far produced massive printed materials in the form of leaflets, books and journals, partly thanks to its own publication company called Pustaka Thariqul Izzah located in Bogor. Dozens of books, mostly translations from Arabic, have been produced from this publication. Its bulletin, alIslam, and its journal, $A l-W$ a iie help spread HTI's ideas more rapidly to the society. These printed materials are open to the public and are sold in several well-known local bookstores, so that any individual outside the inner circle can have immediate access to them. The publications are made possible in part by the contribution of Badan Wakaf al-Salam, HTI's philanthropy body to channel the distribution of rakat (almsgiving) and organize fund-raising activities to fund the publication of its printed materials. This institution contributes to delegating HTI's outstanding preachers into public mosques in Jakarta and its surrounding areas, in addition to seminars and conferences. ${ }^{34}$

The concept of Khila Islarijath is not perceived as the end of HTI's journey, but rather as a means (thripala) to realize the implementation of Islam at a practical level. The objective is to make and disseminate Islam as a blessing to the entire universe (rahthatan li al-armin. This objective, according to HTI, can only be achieved through systematic and planned steps by pious and committed Muslims who dedicate their life to God's cause. Nevertheless, the Khila has become one of the main concerns of HTI because the

\footnotetext{
32 “Hizbut Tahrir Siap Gandeng Parpol," Sindo, 13 August 2007.

33 Ibid.

${ }^{34}$ Ibid., pp. 142-43.
} 
leadership of Muslims will determine the destiny of Islam in its future. Even though HTI does not agree with the existing state system in Indonesia, a coup d'etat to overthrow the constitutional government of the country is regarded as unlawful. This view was also upheld during the presidency of Megawati Sukarnoputri, despite the calls from some Muslim groups to reject her simply because she is a woman. HTI is thus concerned with replacing the system, not individual persons. This is partly because attempts to transform the public will be more effective by means of system..$^{35}$

In contrast to other Islamist groups which are more often easily trapped in excommunication attitudes towards the other, HTI seems to be more moderate in the sense that it does not position itself as the only true representation of Islam. This organization views differences in interpreting Islam as taken for granted, an undeniable fact that should not lead to internal conflict among Muslims. HTI proponents consider this as a matter of ikbtilaf (variation in religion), which is

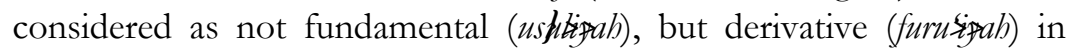
religion. It is assumed that there can be no black-and-white type of understanding religion. Rather, there can be grey and no one can claim his understanding of Islam as the only true version of Islam. In any case, differences can be resolved by referring to the soundest argument. ${ }^{36}$

In terms of religious thought, HTI tolerates differences in understanding religion insofar as it is not related to the fundamentals of religion, such as the issue of secularism in Islam propagated by liberal Muslim activists. In HTI's view, a firm standing must be upheld with regards to the issue of secularism in religion, and there are only two choices to be taken: either right or wrong. HTI activists argue that it is inherent in the Islamic nature that politics must be integrated into religion (dima al-dawlah). Notwithstanding HTI's firm stance towards this issue, it does not excommunicate liberal Muslim activists as ka (apostates). They consider them still as Muslims, but their thinking is in deviation from (true) Islam. In this regard, the official attitude of HTI is more similar to that of mainstream organizations such as Muhammadiyah and NU.

\footnotetext{
35 Endang Turmudi and Riza Sihbudi (eds), Islam dan Radikalisme di Indonesia, pp. 277-8.

36 Ibid., pp. 278-9. Isma'il Yusanto, Interview, Jakarta, 11 May 2005.
} 
HTI denounces liberal Muslim activists on the grounds that the latter do not support the implementation of Shari $\rightarrow$ Nevertheless, HTI does not need to launch rage or hostility, let alone physical violence, against them. HTI is of the view that deviant thinking cannot be opposed by violent acts, but by thinking. Only by this way, they believe, can the Muslim community at large reflect upon which viewpoint is acceptable. Such a response is diametrically opposed to that of other Islamist groups that resist fiercely the thinking of Muslim liberals by means of terror and physical threats. ${ }^{37}$

\section{Social Construction of Anti-Democracy Discourses}

It is noteworthy that the antagonistic attitude of Indonesian Islamists towards democracy is not constructed on a vacuum spot; their anti-democracy discourses are socio-politically constructed. Despite the fact that normative texts such as the Qur'aßand Hadith do not explicitly mention democracy or the like, Islamists prove to be able to show their knack at basing their arguments on textual and normative justification. This underpinning is then forged by contextualizing their textual arguments with logical grand-narratives of the current socio-political circumstances as well as their past memories of historical Islam. In order to amplify this argument, Indonesian Islamists aggrandize the agony of Muslims all over the world who are imagined to be under siege and the oppression of God's enemies. They deplore the moral decay rampant in current Indonesian politics as well as corruption and political conflicts among the elites, assuming that these stem from the blind adoption of democracy. The only single solution to this problem, in their point of view, is Islam.

For Islamists in general and HTI activists in particular, language plays a crucial role in producing and reproducing discourses and counter-discourses. ${ }^{38}$ Discourses on democracy developed by Islamists are of course political, as can be detected in the lexicons and semantics of any other language. Shapiro, following Foucault, observes that the

\footnotetext{
37 Ulil Abshar-Abdalla, a liberal Muslim activist was given a death sentence by MUI Bandung for his controversial column in a national newspaper. He was also threatened by a clandestine JI activist with murder but neglected after he found that a death penalty must be executed by an authoritative body.

38 For further information on Wittgenstein's "language game theory," see Ludwig Wittgenstein, Philosophical Investigations (Oxford, UK: Basil Blackwell, 1958).
} 
use of language is determined by discourse. ${ }^{39}$ That Islamists, for instance, prefer the use of their own heritage language (Arabic) over the language of those who invented or were influenced by Western worldviews is indeed political. That the former speak a language that minimizes the import of either direct idioms or words from anything English or Dutch is also very political. Language in this context is deployed not only as a matter of maintaining a certain cultural identity or simply as ideas exchange, but also as a conduit of maintaining and preserving the purity of Islamic culture. This means that for Islamists culture does really matter for their "inner" identity through which the soul of Islam can be transmitted without corruption and innovation. It is not surprising that in order to keep their Muslimhood preserved Islamists are concerned with the use of idioms and words that are derived directly from the sacred texts which are in Arabic. Along with this course, maintaining normative Islam as it is in Arabic is a part of power aggregation. It is also within this context that anti-Westernism and anti-Americanism are among the most exploited symbols in the Islamists' discourses in their rejection of democracy, especially by depicting democracy as an un-Islamic, corrupt and unholy political system.

The social construction of an enemy is neither peculiar to Islamists in Indonesia, nor is it a new development in politics of Islamism more generally. ${ }^{40}$ In this regard, religious language taken from the texts is an integral part of the construction of evil. Despite their different backgrounds, religious texts provide a plethora of names, labels and symbols that can be deployed readily by Islamists to identify their enemies in specific circumstances. Taghue, Ya'jupand Ma'ju>> Dajjal, jarlizat (ignorance), shayt (devil), ka (unbeliever), munkar (evil), and many others are among the most popular labels found in the Qur'a ${ }^{41}$

39 Michael Shapiro, Language and Political Understanding (Michigan: UMI Out-Of-Print Books on Demand, 1981), p. 24.

40 Constructing Muslims as a new enemy has been a hotly debated issue since the September 11 tragedy. One of the debates has been codified by Emran Qureshi and Michael A. Sells (eds), The New Crusades: Constructing the Muslim Enemy (New York: Columbia University Press, 2003).

${ }^{41}$ Such labels that can be easily found in the Qur'an can lead to a sense of self-fulfilling prophecy, particularly in a negative sense. Most Islamists deploy such labels to portray the contemporary situation of their time and to predict the trajectory of themselves and their enemies in the future. 
Those names and labels are used to describe bad characters and profiles that are supposed to be in opposition to God's side. Whatever idea emerges from the non-Muslim world, but especially the West and its allies, will be identified as evil and, thus, deserves to be treated as enemy. Capitalism, socialism, communism, secularism, democracy, liberalism, pluralism, and individualism are clear examples of Islamists' enemies from outside. Islamists believe that combating these enemies is in the Path of God (Sabi A Alla $>$ which necessitates struggle (jiba) both in a physical sense, i.e. war, and a non-physical sense, i.e. intellectual (ghazw al-fikr) and spiritual. The bad images of God's enemies are boosted through a series of ill-treated experiences of Muslims such as US invasions of some Muslim lands, bad treatment towards Muslim prisoners accused of being terrorists, Zionist campaigns in support of Israel and racial discrimination towards Muslims at home and abroad. ${ }^{42}$

Although anti-Westernism and anti-Americanism did not influence the mainstream of Indonesian Islam, its existence still contributes to a wider social milieu conducive to the longer-term political survival of Islamist groups. In other words, when uttered by ostensibly respectable mainstream politicians, anti-Americanism is afforded a degree of social legitimacy that creates a space for militant and terrorist groups whose agendas rest on the belief that the US poses a direct threat to Muslims in general and to Indonesian Muslims in particular. These anti-American discourses can therefore help such groups recruit adherents from those small pockets of Indonesian society that have lost faith in the promises of secular democracy. ${ }^{43}$ This latter mindset risks creating an atmosphere that tolerates fund-raising and recruitment for anti-American violence elsewhere in the world. However we understand this potential, there is a need to also understand how culture and identity, especially Islamic identity, have been instrumentalised within Indonesian politics.

Conspiracy theories are complementary to the discourses of antidemocracy developed by Indonesian Islamists. The conspiracy theories

\footnotetext{
42 David Wright-Neville, "Anti-Westernism, Indonesian Democracy and the 'Politics of Dashed Expectations'," in Margaret Kartomi (ed.), The Year of Voting Frequently: Politics and Artists in Indonesia's 2004 Elections, Annual Indonesia Lecture Series Number 27 (Clayton: Monash Asia Institute, 2005), pp. 115-16.

${ }^{43}$ Ibid., p. 116.
} 
used may be traced back to numerous anti-Western, anti-capitalist, anti-bourgeois or anti-liberalism discourses where it comes to provide a more or less coherent ideological idioms and jargons: the "West," "Liberalism," "Capitalism," "Modernity," "Christianity-Zionism," and so forth. ${ }^{44}$ It is likely that the demonization of the US and the West in general, to a large extent, is created by Islamists as a response to the same demonization made by the US towards the Islamists, particularly in the post-September 11 era. ${ }^{45}$ They suspect that the demonization of Islam by the US happens in tandem with the global project of the US' war on terrorism which has sketched a notoriously bad image of radical Islamists and Jihadists. ${ }^{46}$ Interestingly enough, Islamists in Indonesia do not deny the existence of global Jihadists. They also admit that Jihadists such as Imam Samudra, Azahari Husin, Noordin Mohd. Top and others were behind several violent attacks in Indonesia. However, Islamists believe more in conspiracy theories than in the pure ideology of Jihadism as the mastermind of terrorism attacks. Yusanto, for instance, believes that a well-planned intelligence operation was behind those attacks. He assumes that there was a subtle infiltration of Islamist groups to instill the false doctrine of jibatand istishba (martyrdom). The purpose was to create the image that Indonesia is a hotbed of terrorism. In his view it is strange that there was little damage inflicted on the actual target, which were the US and

\footnotetext{
${ }^{44}$ For further discussion on conspiracy theories see, among others, Leonidas Donskis, "The Conspiracy Theory, Demonization of the Other," Innovation, vol. 11, 3 (1998): pp. 349-360.

${ }^{45}$ For a discussion on how the US constructs its enemy particularly after September 11 see, among others, Eleanor Stein, "Construction of an Enemy," Monthly Review 55, 3 (Jul/Aug 2003), pp. 125-29. For the socio-political construction of the enemy among Indonesian Islamists see, for instance, Farid Wajdi, "Propaganda Jahat Bush terhadap Islam dan Khilafah," under the rubric Opini Anda, available at: http://hizbuttahrir.or.id/main.php?page $=$ opini\&id=21, accessed on 14 December 2005. See also, "Bush Perjelas Permusuhannya terhadap Islam dan Sistem Khilafah," weekly editorial, 25 October 2005, available at: http://hizbut-tahrir.or.id/main.php?page=editorial\&id=16, accessed on 14 December 2005; cf. "Mewaspadai Upaya Penghancuran Islam," Buletin al-Islam, edition 254, 14 May 2005, available at: http://hizbuttahrir.or.id/main.php?page=alislam\&id=254, accessed on 15 December 2005.
}

46 M. Ramdhan Adhi, "Strategi AS di Dunia Islam Pasca 11/9," Al-Wa'ie, No. 61 (September 2005), available at: http://hizbut-tahrir.or.id/main.php?page=alwaie\&id$=81$, accessed on 14 December 2005 . 
its alliance partners. ${ }^{47}$ Rather, the attacks damaged local people and Indonesia in general.

Terrorist acts in Indonesia are nothing more than "terorisme jadi-jadian" (fabricated terrorism). They're based on an order, they're a fake. There was a strong sense of infiltration, provocation, and radicalization among the Muslims, to create a certain stigma. Azhari is dead already. The logic is that the terrorism threats should be over now that the performer is dead. But he is only a wayang (puppet), not a dalang (performer). If the performer is still alive, there will be other plots and other actors. I believe in this scenario. 48

In other words, Islamists argue that the US and its allies are the great masterminds behind those jihadist operations, to undermine the power of Islam. This is so because the US and the West, rather than Islam and the Muslims, which are perceived to be in a weak position, are dominating the world by means of capitalism. The Islamists depict Muslims as the victim of globalization and they point their finger blame to the US and the West in general. ${ }^{49}$

Islamist discourses of anti-democracy are wrapped within modern arguments and narratives. Even though there is a sense of simplification, generalization, and exaggeration, the demonization done by Islamists is constructed in more advanced arguments and narratives that sound logical and thought-provoking. In constructing their arguments, they use sophisticated structural analyses, especially conspiracy theories, which tend to justify the arguments of postcolonial critics to the West. Thus they share their arguments with postcolonial and post-modernist critics to modernity, which is considered as morally wicked and corrupt. ${ }^{50}$

\footnotetext{
${ }^{47}$ HTI, "Islam Jadi Korban Terorisme, padahal korban bom di Indonesia kebanyakan beragama Islam," http://hizbut-tahrir.or.id/main.php?page=news\&id=279, accessed: 12 February 2007.

48 Ibid.

49 See HTI, "Konspirasi Kafir Barat Menyerang Ummat Islam," Bulletin al-Islam, No 2313 September 2000 available at: http://hizbut-tahrir.or.id/main.php?page=alislam\&id $=23$.

${ }^{50}$ For an interesting account of the Islamists' paradigm of looking at modernity see, for instance, Roxanne L. Euben, "Premodern, Antimodern or Postmodern? Islamic and Western Critiques of Modernity," The Review of Politics 59, 3 (Summer 1997), pp. 429-459.
} 
Democracy is perceived as something derived from the enemies of God who have been engaged in ceaseless attempts to subjugate Muslims all over the world, especially in the lands of Palestine, Afghanistan and Iraq. Islamists are also convinced that Muslims are under siege from God's enemies who are destroying Islam step by step. By this definition, Indonesian Islamists are constructing the concept of enemy in light of the self-fulfilling prophecy on the basis of the sacred texts which are used as a mirror to define themselves and their enemies. ${ }^{51}$ The construction of the enemy is thus very much influenced by prejudice and the ideology of hatred. In order to strengthen the differences between their own identity and that of the enemy, Islamists use the logics of binary opposition to erect a wall of virtues which separates them from the others. They describe themselves as pious and the chosen community as mandated by the sacred texts whose responsibility it is to give the rest heavenly guidance and salvation. By doing so, the rest is defined as whatever they themselves are not.

In an article written by Denny Kodrat, the Chief of Lajnah Siya [the Commission of Politics] of HTI of West Java, for instance, the construction of the enemy is raised partly as a reply or a kind of selfdefense in response to the Bush administration's paradigm of the "axis of evil", which is mainly directed against Islam and Muslims. ${ }^{52}$ In this article, the writer asks a rhetorical question to denounce the Bush administration's demonizing of Islam and Muslims: "Who is ideologically evil?" In his opinion, when the US is pointing its finger to Islam and Muslims as the axis of evil, it is basically pointing its finger to itself as the real Satan of the world. In supporting this argument, Kodrat refers to Noam Chomsky's criticism of the US with the use of parable as follows: "Alexander the Great captured a pirate and asked, "Why do you make a terror in the sea?" The pirate replied, "Why do you make a chaos in the world? Because I use a small ship, you call me a terrorist; and you? Because you do with a huge ship you are called a Caesar!" 53

\footnotetext{
${ }^{51}$ James A. Aho, This Thing of Darkness, especially pp. 23-34.

52 Denny Kodrat, "Barat dan 'Ideologi Setan," Al-Wa'ie, edition 61, available at http://hizbut-tahrir.or.id/main.php?page $=$ alwaie\&id=70, accessed on 13 December 2005.

${ }^{53}$ Chomsky's critical ideas towards the US have been widely shared by HTI activists in expounding the conspiracy theories of the US to undermine the power of Islam.
} 
In his article, Kodrat shortlists the historical sins done by the US to the world. He accuses the US of being responsible for numerous conflicts and civil wars after World War II, including conflicts in Greece (1947-1949), Italy (1948), Korea (1950-1953), Iran (1953), Guatemala (1954), Zaire (1960), Cuba (1961), Vietnam (1961-1975), Dominica (1965), Kampuchea (1969-1971), Chili (1973), Grenada (1983), Lebanon (1958 and 1983), Libya (1986), Panama (1989), Iraq (1991, 1993, 1998-1999 and 2003-now), Somalia (1991-1992), Afghanistan (1998-2002), and Serbia (1999). ${ }^{4}$ Many of the US military operations in these conflicts indicate that this country is too ambitious to control the world in order to maintain its hegemony and defend its economic interests. This, in Kodrat's opinion, also shows how ugly the face of capitalist ideology is as practiced by the US through its vulgar imperialism, wrapped in false slogans such as "pre-emptive strike," "internal security," "world order, and "international peace."

In Kodrat's opinion, the West's accusation that Islam represents a satanic ideology which is against human rights, democracy and freedom, which is prone to terror and conflict, and which deploys physical violence as a means of achieving ideological purposes deserves to be questioned further. If these accusations are used as a standard to demonize a certain ideology, it is the West that should be accused first of having a satanic ideology. In his view, there are several reasons to explain this argument.

First, in terms of the appreciation of human rights, one sees that the capitalist ideology in its early stage tends to side with the elites whose huge economic capital is unfavorable to the oppressed. As an illustration, he goes on to argue, when the world became aware of the pollution through gas emissions produced by the industrial countries, they aggregated to overcome this problem by making an agreement among them called the Treaty of Kyoto (Kyoto Protocol). Despite the conflict of interests among some of the developed countries, the treaty has been eventually ratified by most of the world's nations, except the US and Australia, countries with extremely high amounts of gas emissions.

Chomsky's book, Maling Teriak Maling: Amerika Sang Teroris?, published by Mizan [Bandung] in 2001, a translated version of his book, entitled September 11, was among the bestsellers widely consumed after the September 11 tragedy. See Noam Chomsky, September 11 (Crows Nest, NSW: Allen \& Unwin, 2001).

${ }^{54}$ Denny Kodrat, "Barat dan 'Ideologi Setan.”" 
Another lucid example regards the legality of abortion. ${ }^{55}$ As the industrial countries legalize abortion as a consequence of the tradition of free sex, this policy contradicts the very fact that the state guarantees the people's right to live, because abortion represents the confiscation of an infant's right to live. To support his argument, Kodrat refers to statistical data released by Henshaw and Morrow (1990), stating that the largest share of abortions in the world is ironically undertaken in the following industrial countries: the US, Denmark, Sweden, Italy, Norway, Finland, Canada, Netherlands, France, United Kingdom, and New Zealand.56 The high levels of abortion bring about cultural dissemination among Western societies as if killing is a legal action. When the state legalizes abortion due to materialistic reasons (utilitarianism), it is clear that the state is unable to protect human rights, one of which is the right to live for the infant. This reflects the inability of the state to safeguard the right to live, one of the most elementary human rights. ${ }^{57}$

Second, with regards to the Bush administration's war on terrorism, Kodrat argues that the real and greatest terrorist with the biggest amount of casualties throughout the history of mankind is the West, not Islam. Kodrat refers to some events throughout the history of Western civilization which resulted in bloodshed, particularly the chaotic turmoil during the Medieval Ages, the Crusades, and the first and second World Wars. For the West, Kodrat argues, massacre is a ritual to force its ideology upon others. In the case of the Crusades, for instance, while Saladin freed al-Quds without bloodshed, the Crusade warriors did the contrary. The blood of Muslims had to be spilled due to the atrocities perpetrated by the Crusade warriors. The same thing happened when the US military forces invaded some Muslim lands such as Iraq and Afghanistan. The maltreatment of Muslim prisoners and the harassment of the Qur'an in Guantanamo Bay and Abu Ghraib prisons have notoriously bolstered the satanic character of the US and its capitalism and democracy. With the support of the principle

55 A formal statement has recently been released by HTI regarding its rejection of abortion. See Kantor Jubir HTI, "Pernyataan Hizbut Tahrir Indonesia: Menolak Legalisasi Aborsi," issued on 14 September 2005, available at: http://hizbuttahrir.or.id/ver/lowres/main.php?page=jubir\&id=15, accessed on 17 December 2005.

${ }^{56}$ The book Kodrat is referring to is S.K. Henshaw and E. Morrow, Induced Abortion: A World Review, 1990 Supplement (Geneva: Alan Guttmacher Institute, 1990).

${ }^{57}$ Denny Kodrat, "Barat dan 'Ideologi Setan.”" 
"the end justifies the means," the Machiavellian ideology of capitalism is allowed to do anything necessary for the sake of its own interests such as agitation, violence and anarchism, regardless of its destructive impacts on others.

Third, the idea of freedom echoed by Western capitalist countries is not more than an illusion and myth. ${ }^{58}$ As soon as freedom is counter-productive to its ideology, the state will consequently amputate it. This was the case in France where the government banned all types of religious symbols in public life, including the headscarf for Muslim women, even though this country claims to adopt democratic freedom of expression and religion. Why is Hizbut Tahrir considered illegal in Germany although this country claims to be open-minded and respectful towards freedom of expression? Why is Iran not allowed to advance its nuclear energy project while at the same time many Western countries develop the same project? These are the questions that will finally open up the moral wickedness of capitalism and democracy. So, when the West pinpoints Islam as a satanic ideology, the fact is that it is pinpointing at itself as the real satanic ideology, Islamists go on to argue. It is the double standard of the West in implementing democracy that Islamists constantly criticize.

Significantly, the notion of enemy is not only constructed in response to external enemies. Enemies can threaten from within as well, i.e. from their co-religionists upon whom they predicated as "deviant" Islam..$^{59}$ This is to invoke the sense of being under constant siege both externally and internally. They denounce their co-religionists -especially those from the NGO and intellectual activist scene funded by international agencies - who campaign for democratization, human rights, gender equality, pluralism, and liberalism, as agents of the West seeking only to destroy Islam from within. Ulil Abshar-Abdalla with

58 This opinion is also shared by Farid Wajdi, "Larangan Jilbab dan Mitos Demokrasi," Pikiran Rakyat, Opinion Column, 19 January 2004; cf. his "Motif Sesungguhnya Pelarangan Hijab," available at http://swaramuslim.net/more.php?id=1661_0_0_1_0_M, accessed on 17 July 2005.

${ }^{59}$ M. Shiddiq al-Jawi, Ushul Fiqh Palsu Kaum Liberal," $A$-Wa'ie, edition 56, available at: http://hizbut-tahrir.or.id/main.php?page=alwaie\&id=7, accessed on 16 December 2005; cf. M. Shiddiq al-Jawi, "Kelompok Liberal itu Agen Penjajah," al-Wa'ie, edition 58, available at: http://hizbut-tahrir.or.id/main.php?page $=$ alwaie\&id $=34$, accessed on 16 December 2005. 
his JIL team (Jaringan Islam Liberal/Liberal Islam Network) has been resisted severely as one of the enemies from within. ${ }^{60}$

Even though the US has done quite a lot to deal with the issue of terrorism under the project of "War on Terror" - such as military intervention in Iraq and Afghanistan, providing a great deal of funding to support the bills of anti-terrorism in many Muslim countries, persuading the regimes of countries serving as its agents to arrest "Muslim hard-liners," provoking Muslims through the tongue of leaders of its proxy countries such as John Howard, the Prime Minister of Australia, Lee Kuan Yew, the Senior Minister of Singapore, and Goh Tjok Tong, the Prime Minister of Singapore, and so forth - the US seems to need other hands taken from within to fight against Islam and Muslims, namely secularized liberal activists such as Ulil AbsharAbdalla and his colleagues of Liberal Islam Network (JIL). ${ }^{61}$

Since the collapse of Soeharto's New Order regime, the same pattern of constructing an enemy has also been established to denounce the existing regime as un-Islamic and pro-Western. Abdurrahman Wahid, the former respected leader of Nahdlatul Ulama (NU) and former Indonesian president, has been targeted by Islamists' resentment due to his support for democracy. Likewise, the last two presidents - Megawati Sukarnoputri and Susilo Bambang Yudhoyono - have also been criticized as being controlled by capitalist powers due to their support for democracy.

\section{Conclusion}

From the above description we learn that the HTI activists' rejection of democracy is constructed not only on theological basis but also on socio-political one. In most cases, theological arguments are complimentary in so far as the socio-political arguments need further support. This means that socio-political arguments come first prior to theological ones. The Islamists usually refer to current socio-political constellation as their main reference of repudiating the idea democracy by keep arguing that within democracy lie all kinds of socio-political decay. Islam, they maintain, serves as the only solution for all maladies made by humans since Islam is a heavenly entity revealed to all human

${ }^{60}$ Farid Wadjdi, "Tiga Agenda Menghadapi Pemikiran Liberal," Hayatulislam.com, 26/05/2005.

${ }^{61}$ HTI, “Islam Liberal: Liberalisme Berbaju Islam,” Buletin Al-Islam (1 January 2003). 
beings, not only to Muslims. By means of transnational system of

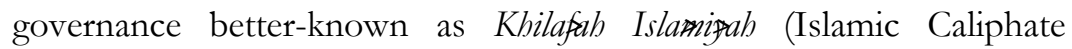
system) they believe that the shortcomings of man-made ideologies can be solved. It is only such a political system that is able to ensure the harmony among civilizations and secure the rights of non-Muslim community even though it is not clear whether the non-Muslims will have the equal rights as Muslims do.

All entities outside of Islam such as democracy are perceived as something derived from the enemies of God who are presumed to threaten and subjugate Muslims all over the world. Democracy is a part of human's revolt against God. Under the system of democracy, sovereignty lies at the hands of the people where people can produce laws that contradict Islamic law. It is within this reason that the Islamists will not let all man-made entities rule over humankind. Along with this, Indonesian Islamists are constructing the concept of enemy based on the concept of binary opposition between the "authentic" selves and the "corrupted" ones. They describe themselves as pious, authentic and unadulterated whose responsibility is to assist the rest with heavenly guidance and salvation. By doing so, the rest is defined as whatever they themselves are not.

Warriors need enemies, without which the self will mean nothing. The entity of the enemy is not something constructed in a vacuum, socially and politically. This means that the concept of enemy is ontologically constructed for the purpose of self-fulfilling prophecy. To the Islamists, the word enemy can take different forms from time to time, contingent upon the context of when and where Islam is present. The process of socio-political construction of the enemy follows what Berger and Luckmann have itemized: naming, legitimation, mythmaking, sedimentation, and ritual.

For Islamists in general and HTI activists in particular, language plays a crucial role in producing and reproducing discourses and counter-discourses. Discourses on democracy developed by Islamists are of course political, as can be detected in the lexicons and semantics of any other language. Language in this context is deployed not only as a matter of maintaining a certain cultural identity or simply as ideas exchange, but also as a conduit of maintaining and preserving the purity of Islamic culture. This means that for Islamists culture does really matter for their "inner" identity through which the soul of Islam can be transmitted without corruption and innovation. It is not 
surprising that in order to keep their Muslimhood preserved Islamists are concerned with the use of idioms and words that are derived directly from the sacred texts which are in Arabic. In line with this, maintaining normative Islam as it is in Arabic is a part of power aggregation. Likewise, anti-Westernism and anti-Americanism are among the most exploited symbols in the Islamists' discourses in their rejection of democracy, especially by depicting democracy as an unIslamic, corrupted and "unholy" system of governance. []

\section{Bibliography}

\section{Books and Articles}

Adhi, M. Ramdhan. "Strategi AS di Dunia Islam Pasca 11/9." AlWa'ie, No. 61 (September 2005), available at: http://hizbuttahrir.or.id $/$ main.php?page $=$ alwaie\&id $=81$, accessed on 14 December 2005.

Aho, James A. This Thing of Darkness: A Sociology of the Enemy. Seattle and London: University of Washington Press, 1994.

Al-Jawi, M. Shiddiq. "Kelompok Liberal itu Agen Penjajah." al-Wa'ie, edition 58, available at: http://hizbut-tahrir.or.id/main.php?page $=$ alwaie\&id $=34$, accessed on 16 December 2005.

-------.. "Ushul Figh Palsu Kaum Liberal." Al-Wa'ie, edition 56, http:/ /hizbut-tahrir.or.id/ main.php?page=alwaie\&id=7, accessed on 16 December 2005.

Al-Nabhani, Taqiyuddin. Pembentukan Partai Politik Islam. Bogor: Thariqul Izzah, 2002.

Arbib, Michael and Mary Hesse. The Construction of Reality. Cambridge: Cambridge University Press, 1986.

Berger, Peter and Thomas Luckmann. The Social Construction of Reality. Garden City, N.Y.: Doubleday-Anchor, 1967.

Berger, Peter L. The Sacred Canopy. New York \& London: Anchor Books, 1990.

Chomsky, Noam. Maling Teriak Maling: Amerika Sang Teroris?. Bandung: Bandung, 2001.

Dhume, Sadanand. "Hizbut Tahrir Using War in Iraq to Seek Converts." Far Eastern Economic Review, April 3, 2003. 
Donskis, Leonidas. "The Conspiracy Theory, Demonization of the Other." Innovation 11, 3 (1998): pp. 349-360.

Euben, Roxanne L. "Premodern, Antimodern or Postmodern? Islamic and Western Critiques of Modernity," The Review of Politics 59, 3 (Summer 1997): pp. 429-459.

Fuller-Collins, Elizabeth. "Islam is the Solution: Dakwah and Democracy in Indonesia," unpublished paper (http://www.classics.ohiou.edu/faculty/collins/islamsolution.pdf).

Hallaq, Wael B. "Was the gate of Ijtihaclosed?," in I. Edge (ed.), The International Library of Essays in Law \& Legal Theory: Legal Cultures, 7. Aldershot: Dartmouth (1996): pp. 287-325.

Henshaw, S.K. and E. Morrow, Induced Abortion: A World Review, 1990 Supplement. Geneva: Alan Guttmacher Institute, 1990.

Hizbut Tahrir Indonesia (HTI), "Islam Jadi Korban Terorisme, padahal korban bom di Indonesia kebanyakan beragama Islam," http:/ / hizbut-tahrir.or.id/main.php?page= news\&id=279, accessed: 12 February 2007.

------. Konspirasi Kafir Barat Menyerang Ummat Islam,” Bulletin alIslam, No 23, 13 September 2000 available at: http://hizbuttahrir.or.id $/$ main.php?page $=$ alislam\&id $=23$.

-. "Islam Liberal: Liberalisme Berbaju Islam," Buletin Al-Islam (1 January 2003).

-. "Pernyataan Hizbut Tahrir Indonesia: Menolak Legalisasi Aborsi," issued on 14 September 2005, available at: http://hizbut-tahrir.or.id/ver/lowres/main.php?page=jubir\&id=15, accessed on 17 December 2005.

Hizbut Tahrir. The Methodology of Hizbut-Tahrir for Change. London: AlKhilafah Publications, n.d.

Jamhari \& Jajang Jahroni (eds). Gerakan Salafi Radikal di Indonesia. Jakarta: Rajawali Press, 2004.

Karuvelil, George. "Constructing 'God': A Contemporary Interpretation of Religion," HeyJ XLI (2000): pp. 25-46;

Kodrat, Denny. "Barat dan 'Ideologi Setan," Al-Wa'ie 61, http:/ hizbut-tahrir.or.id/ main.php?page $=$ alwaie\&id $=70$, accessed on 13 December 2005. 
Qureshi, Emran and Michael A. Sells (eds). The New Crusades: Constructing the Muslim Enemy. New York: Columbia University Press, 2003.

Roy, Olivier. Globalised Islam: The Search for a New Ummah. London: Hurst, 2004, 9.

Salim, Agus. "The Rise of Hizbut Tahrir Indonesia (1982-2004): Its Political Opportunity Structure, Resource Mobilization, and Collective Action Frames." Jakarta: UIN Syarif Hidayatullah Jakarta, Masters Thesis, 2005.

Shain, Ralph. "Situating Derrida: Between Kierkegaard and Hegel." Philosophy Today 44, No. 4 (Winter 2004): pp. 388-403.

Shapiro, Michael. Language and Political Understanding. Michigan: UMI Out-Of-Print Books on Demand, 1981.

Stein, Eleanor. "Construction of an Enemy." Monthly Review 55, 3 (Jul/Aug 2003): pp. 125-29.

Taji-Farouki, Suha. A Fundamental Quest: Hizb al-Tabrir and the Search for the Islamic Caliphate. London: Grey Seal, 1996.

Turmudi, Endang \& Riza Sihbudi (eds), Islam dan Radikalisme di Indonesia. Jakarta: LIPI Press, 2005.

Voll, John Obert. Islam, Continuity and Change in the Modern World. Boulder, Colorado: Westview Press, 1982.

Wadjdi, Farid. "Tiga Agenda Menghadapi Pemikiran Liberal," Hayatulislam.com, 26/05/2005.

-. "Larangan Jilbab dan Mitos Demokrasi," Pikiran Rakyat, 19 January 2004.

-. "Mewaspadai Upaya Penghancuran Islam," Buletin al-Islam 254, 14 Mei 2005 (http:/ /www.hayatulislam.net/weblog.php?id=C36_8_1), accessed 12 December 2005

-. "Propaganda Jahat Bush terhadap Islam dan Khilafah," under the rubric Opini Anda, available at: http://hizbut-tahrir.or.id/main.php?page $=$ opini\&id $=21$, accessed on 14 December 2005.

-. "Bush Perjelas Permusuhannya terhadap Islam dan Sistem Khilafah," weekly editorial, 25 October 2005, available at: http:/ / hizbut-tahrir.or.id/main.php?page=editorial\&id $=16$, accessed on 14 December 2005. 
Weiss, B. "Interpretation in Islamic Law: the Theory of Ijtibat? in I. Edge (ed.), The International Library of Essays in Law \& Legal Theory: Legal Cultures, 7. Aldershot: Dartmouth (1996): pp. 273286.

Wittgenstein, Ludwig. Philosophical Investigations. Oxford: Basil Blackwell, 1958.

Wright-Neville, David. "Anti-Westernism, Indonesian Democracy and the 'Politics of Dashed Expectations," in Margaret Kartomi (ed.), The Year of Voting Frequently: Politics and Artists in Indonesia's 2004 Elections, Annual Indonesia Lecture Series number 27 (Clayton: Monash Asia Institute, 2005): pp. 105-122.

\section{Newspapers}

"Hizbut Tahrir Indonesia: Dakwah Masjid yang Menggurita," Sabili, No. 9/XI, special edition, 2003.

“Hizbut Tahrir Siap Gandeng Parpol," Sindo, 13 August 2007.

\section{Websites:}

http://www.hizb.org.uk/hizb/global-photos/in-pictures-hti-international-khilafah-conference.html.

http://www.hizbuttahrir.org.uk.

http:/ /www.khilafah.com/kcom/activism/asia/international-khilafahconference-2007.html. 